\title{
NERIUM OLEANDER LINN. IN VITRO ALPHA AMYLASE INHIBITORY POTENTIAL OF STEM AND ROOT EXTRACTS
}

\section{MEENAKSHI FARTYAL}

\author{
Laboratory of Plant Tissue Culture and Secondary Metabolites, Department of Botany, University of Rajasthan, Jaipur, India
}

Email: mksh35@gmail.com

Received: 01 Oct 2016, Revised and Accepted: 05 Dec 2016

\section{ABSTRACT}

Objective: Extraction and evaluation of the antidiabetic activity of extracts from stem and roots of Nerium oleander (Apocynaceae) Linn.

Methods: Stem and roots of $N$. oleander were collected, dried and extracted by using well-established methods for alkaloids, flavonoids, steroids and crude extracts in polar and non-polar solvents. Evaluation of their antidiabetic activity was done with salivary alpha-amylase and starch as a substrate using chromogenic DNSA (2,4-Di nitro Salicylic Acid) method and Starch-iodine method. All experiments were performed in 3 different sets each in triplicates. The data are expressed as mean \pm SEM (standard error of the mean).

Results: The highest inhibition for stem was found in its free flavonoid extract at the concentration of $1.5 \mathrm{mg} / \mathrm{ml}$, with percent inhibition $48.35 \pm 1.36 \%$ and an $\mathrm{IC}_{50}$ value of $1.774 \mathrm{~g} / \mathrm{ml}$ while in case of root, highest inhibition was obtained at $1.5 \mathrm{mg} / \mathrm{ml}$ of pet ether extract, with $\%$ inhibition $52 \pm 0.40 \%$ and $\mathrm{IC}_{50}$ value $1.583 \mathrm{~g} / \mathrm{ml}$ and at $1.5 \mathrm{mg} / \mathrm{ml}$ of methanol extract, with \% inhibition $42.12 \pm 1.12 \%$ and an IC 50 value $1.729 \mathrm{~g} / \mathrm{ml}$ 8 ( 5 of stem and 3 of root) out of 14 tested extracts have shown good inhibitory potential. Extracts of the stem were found to be more potent than root extracts

Conclusion: Though stem extracts were found to be a more potent hypoglycemic agent than root extracts, however, extracts of both parts have good antidiabetic potential and both might be fruitful in managing the postprandial hyperglycemia.

Keywords: Antidiabetic activity, Alkaloid, Flavonoid, Steroid, Petroleum ether, Methanol, Water, Salivary alpha-amylase, DNSA, Starch

(C) 2016 The Authors. Published by Innovare Academic Sciences Pvt Ltd. This is an open access article under the CC BY license (http://creativecommons.org/licenses/by/4.0/) DOI: http://dx.doi.org/10.22159/ijcpr.2017v9i2.17378

\section{INTRODUCTION}

Diabetes mellitus describes a metabolic disorder of multiple etiology which results in increased blood glucose levels and disturbances of carbohydrates, fats and protein metabolism resulting from defects in insulin secretion, insulin action or both [1]. Anti-diabetic drugs are medicines developed to stabilize and control blood glucose levels and thus manage diabetes [2]. Plants had anchored to the mother earth long before man has set his feet and it is said that god had endowed them with materials for the survival of man and animal long before these creatures were made by him [3]. Herbal remedies have formed the basis of traditional medicine for millennia, and have formed the root of modern pharmacology. While science from roughly the 1880's onwards has striven to isolate the active compounds found in medicinal herbs, the list is ever growing. Herbal medicine is still the mainstay of maximum world population; mainly in the developing countries for primary health care not because they are inexpensive but also for better cultural acceptability, better compatibility with the human body and minimal side effects. To date, however, only a few of these medicinal plants have received scientific scrutiny, despite the fact that the World Health Organization has recommended that medical and scientific examinations of such plants should be undertaken [4]. Lot of information from the traditional healers still to be known and has to be gathered and necessarily formulated [5]. The herbal drugs with antidiabetic activity are yet to be commercially formulated as modern medicines, even though they have been acclaimed for their therapeutic properties in the traditional systems of medicine [6]. It is estimated that 1200 species of plants are used for the treatment of diabetes in traditional and ethno pharmacological practices around the world [7]. One such plant is Nerium oleander L. (Apocynaceae) which is known as 'Karabi' by the local Bengali people of West Bengal, India and in Bangladesh, 'Kaner' in most part of India and commonly called 'Oleander' in English. Nerium oleander is used for the treatment of diabetes in different ethno pharmacological and indigenous medicinal systems around the world such as in Morocco
[8-12] and is also mentioned in Ayurveda. Nerium oleander possesses potent anti-diabetic activity [13]. Ethanolic extract of flowers of Nerium oleander was reported to have anti-diabetic activity against alloxan-induced diabetic rats [14].

Nerium oleander extract was reported for improvement in activities of insulin, glucose and liver enzymes in hypoinsulinemic and hyperglycemic albino rats [15]. Nerium oleander was reported for having anti-diabetic agents. These Pancreatic $\alpha$-amylase inhibitors offer an effective strategy to lower the levels of post-prandial hyperglycemia via control of starch breakdown [16]. Nerium oleander was identified to have potent wound healing and antidiabetic activity [17]. Review of the literature indicates that not much work has been done for evaluation of antidiabetic activity of stem and root extracts of this plant. Therefore, stem and root extracts of $N$. oleander Linn. were selected in the present study to determine the hypoglycemic potential of this plant.

\section{MATERIALS AND METHODS}

\section{Plant collection}

Stem and roots of Nerium oleander Linn. were collected from different localities of Jaipur. Shade dried, weighed and stored in containers for extraction purpose.

\section{Extractions}

Extraction of plant parts in different polar, non-polar solvents (Water, methanol and petroleum ether) and for their secondary metabolites (alkaloids, flavonoids and steroids) was carried out by well-established methods.

Extraction of secondary metabolites

\section{Chemicals}

Acetic acid, Ethanol, $\mathrm{NH}_{4} \mathrm{OH}$, Methanol, Petroleum ether, Ethyl ether, Ethyl acetate, Sulphuric acid, $\mathrm{HCl}$ and Benzene. 


\section{Extraction of alkaloids}

Alkaloids were extracted from stem and root of the selected plant by well-established method [18]. Finely powered sample (100g) of stem and root were extracted in $20 \mathrm{ml}$ methanol after shaking for 15 min. After filtration, the filtrates were kept for drying. Thereafter residual mass was treated with $1 \% \mathrm{H}_{2} \mathrm{SO}_{4}(5 \mathrm{ml} .2$ times). Extraction was then done in $10 \mathrm{ml}$ chloroform $\left(\mathrm{CHCl}_{3}\right)$ by using separating funnel. The organic layer of chloroform was rejected, and the aqueous layer was basified with $30 \% \mathrm{NH}_{4} \mathrm{OH}\left(\mathrm{PH}^{\mathrm{H}}=9-10\right)$. Again, extraction was done in $10 \mathrm{ml}$ chloroform and the organic layer of chloroform (lower layer) was collected in a flask, extraction was repeated with fresh chloroform and was dried in vacuo.

\section{Extraction of flavonoids}

Stem and roots of selected plant were subjected to the flavonoid extraction following the method of Subramanian and Nagarjan [19]. One hundred gram of finely powdered sample was soxhlet extracted with $80 \%$ hot methanol $(500 \mathrm{ml})$ on a water bath for $24 \mathrm{~h}$ and filtered. Filtrate was re-extracted successively with petroleum ether (fraction I), diethyl ether (fraction II), and ethyl acetate (fraction III) using separating funnel. Petroleum ether fraction was discarded as being rich in fatty substances whereas diethyl ether and ethyl acetate fraction were analyzed for free and bound flavonoids respectively. The ethyl acetate fraction of sample was hydrolyzed by refluxing with $7 \% \mathrm{H}_{2} \mathrm{SO}_{4}$ for $2 \mathrm{~h}$ (for removal of bound sugars) and the filtrate was extracted with ethyl acetate in separating funnel. Ethyl acetate extract obtained was washed with distilled water to neutrality. Diethyl ether (free flavonoids) and ethyl acetate fractions (bound flavonoids) were dried in vacuo and weighed.

\section{Extraction of steroids}

Steroids were extracted from stem and roots of the selected plant by well-established method [20] after preliminary detection of steroids. Finely powdered sample $(100 \mathrm{~g})$ of stem and root were extracted in petroleum ether for $24 \mathrm{~h}$. After filtration; residual mass was treated with $15 \%$ ethanolic $\mathrm{HCl}$ for $4 \mathrm{~h}$. Extraction was then done in ethyl acetate followed by washing in dis. water to neutralise the extract. The neutral extract was then passed over Sodium sulphate to remove moisture contents and was dried in vacuo. Chloroform was used for reconstitution of extract, filtered, dried and stored for further use.

\section{Extraction of crude extracts in polar and non-polar solvents}

Dry plant material (20 gm each) was taken separately in roundbottomed flask in different polar and non-polar solvents (water, methanol and petroleum ether) in the ratio of 1:10. Soxhlet extraction was carried out for $24 \mathrm{~h}$ and filtered. Each filtrate was subjected to evaporation to obtain crude dried extract which was weighed and calculated for each gram plant material.

\section{In vitro salivary $\alpha$ amylase inhibitory assay}

Starch-iodine color assay

\section{Reagents}

Starch solution (1\%), Phosphate buffer of pH 6.9 and of 0.02 molarity, Iodine reagent, salivary alpha amylase enzyme.

\section{Procedure}

Screening of plant extracts for $\alpha$-amylase inhibitory activity was carried out in test tubes following the method of Xiao [21] with slight modifications based on the starch iodine test. Total assay mixture composed of $120 \mu \mathrm{l} 0.02 \mathrm{M}$ sodium phosphate buffer ( $\mathrm{pH} 6.9$ containing $6 \mathrm{mmol}$ sodium chloride), $1.5 \mathrm{ml}$ of salivary amylase and plant extracts of concentration range $0.5-1.5 \mathrm{mgml}^{-1}(\mathrm{w} / \mathrm{v})$ were incubated at $37{ }^{\circ} \mathrm{C}$ for $10 \mathrm{~min}$. Soluble starch $(1 \% \mathrm{w} / \mathrm{v})$ was then added to each reaction mixture and were incubated at $37^{\circ} \mathrm{C}$ for 15 min. Thereafter $1 \mathrm{M} \mathrm{HCl}(60 \mu \mathrm{l})$ was added to stop the enzymatic reaction, followed by the addition of $300 \mu \mathrm{l}$ of iodine reagent ( 5 $\mathrm{mmol} \mathrm{I}_{2}$ and $5 \mathrm{mmol} \mathrm{KI}$ ). Colour change was observed and the absorbance was recorded at $620 \mathrm{~nm}$. Reaction tubes of control representing $100 \%$ enzyme activity which did not contain any plant extract. To eliminate the absorbance produced by plant extract, appropriate extract controls without the enzyme were also examined. The appearance of dark-blue colour indicates the presence of starch; a yellow colour indicates the absence of starch while a brownish colour indicates partially degraded starch in the reaction mixture. In the presence of inhibitors from the extracts, the starch added to the enzyme assay mixture was not degraded and gave dark-blue colour complex whereas no coloured complex was developed in the absence of the inhibitor, indicating that starch was completely hydrolysed by $\alpha$-amylase.

\section{Glucose-DNSA color assay}

\section{Reagents}

DNSA (2, 4-Di nitro salicylic acid) reagent, Phosphate buffer of $\mathrm{pH}$ 6.9 and of 0.02 molarity, $1 \%$ Starch solution, Salivary alpha amylase enzyme.

\section{Procedure}

Inhibition assay was performed using chromogenic DNSA method [22]. Total assay mixture composed of $500 \mu \mathrm{l}$ of $0.02 \mathrm{M}$ sodium phosphate buffer ( $\mathrm{pH} 6.9$ containing $6 \mathrm{mmol}$ sodium chloride), 1 $\mathrm{ml}$ of salivary amylase and $400 \mu \mathrm{l}$ extracts of concentration ranging from $0.5-1.5 \mathrm{mgml}-1(\mathrm{w} / \mathrm{v})$ was incubated at $37^{\circ} \mathrm{C}$ for 10 min. After pre-incubation, $580 \mu \mathrm{l}$ of $1 \%(\mathrm{w} / \mathrm{v})$ starch solution was added to each tube and were subjected to incubation at $37^{\circ} \mathrm{C}$ for $15 \mathrm{~min}$. The reaction was then terminated by adding $1.0 \mathrm{ml}$ DNSA reagent and each tube was placed in boiling water bath for $5 \mathrm{~min}$., cooled to room temperature and the absorbance was measured at $540 \mathrm{~nm}$. A control containing no plant extracts showed $100 \%$ enzyme activity. To eliminate the absorbance produced by plant extract, appropriate extract controls with the extract in the reaction mixture except for the enzyme were also included (negative control). Percent inhibition of alpha-amylase was calculated as follows:

$\%$ Relative enzyme activity= Enzyme activity in test sample with extract* 100

\section{Enzyme activity in control \\ $\%$ Inhibition in the $\alpha$-amylase activity= (100-\% Relative enzyme activity)}

\section{Statistical data analysis}

All experiments were performed in three different sets, each in triplicate. The data are expressed as mean \pm SEM (standard error of the mean). The statistical difference, ANOVA and linear regression analysis were performed using Graph pad prism 5 statistical software. The $\mathrm{IC}_{50}$ values were determined from plots of percent inhibition versus log inhibitor concentration and calculated by logarithmic regression analysis from the mean inhibitory values. The $\mathrm{IC}_{50}$ values were defined as the concentration of the extract, containing the $\alpha$-amylase inhibitor that inhibited $50 \%$ of the alphaamylase activity.

\section{RESULTS}

Different levels of alpha-amylase inhibitory activity were observed for different tested extracts of stem and root of Nerium oleander Linn. (table 1). Free flavonoid extract of stem part and pet ether extract of root were found to have maximum inhibitory potential. Water and pet ether extract of stem and methanol and water extract of root were also recorded for good alpha-amylase inhibitory activity. Alkaloids of both parts (stem and root) were found to have moderate inhibition potential. All other tested extracts were found to have insufficient amylase inhibitory activity. 
Table 1: Level of alpha-amylase inhibitory activity of different extracts of $N$. oleander Linn

\begin{tabular}{lll}
\hline Name of plant part & Name of extract & Level of inhibitory activity \\
\hline Stem & Alkaloid & + \\
& Steroid & - \\
& Free flavonoid & ++ \\
& Bound flavonoid & - \\
& Pet ether & ++ \\
& Methanol & + \\
Root & Water & ++ \\
& Alkaloid & - \\
& Steroid & - \\
& Free flavonoid & - \\
& Bound flavonoid & - \\
& Pet ether & ++ \\
\end{tabular}

Note: Level: Indication of inhibitory potential of extract, $(++)$ indicated extracts with moderate inhibitory effects on alpha-amylase., $(+)$ indicated extracts with minimum inhibitory effects on alpha amylase activity, (-) indicated extracts with insignificant (no) inhibitory effects on alpha amylase activity.

\section{Extracts with high inhibitory effect on alpha amylase activity}

\section{Stem}

Free flavonoid extract (at a concentration of $0.5-1.5 \mathrm{mg} / \mathrm{ml}$ ) showed the highest alpha amylase inhibition with high percent inhibition $(34.98 \pm 0.07 \%$ to $48.35 \pm 1.36 \%)$ and low $\mathrm{IC}_{50}$ value $(1.774 \mathrm{~g} / \mathrm{ml})$. Water (\% inhibition $=16.33 \pm 0.75 \%$ to $32.13 \pm 1 \%$, $\mathrm{IC}_{50}$ value $\left.=3.813 \mathrm{~g} / \mathrm{ml}\right)$ and pet ether $(\%$ inhibition $=26.07 \pm 0.94$ $\%$ to $37.3 \pm 0.81 \%$, IC 50 value $=4.076 \mathrm{~g} / \mathrm{ml}$ ) extracts were also exhibit good level of alpha amylase inhibition (table 2).

\section{Root}

Pet ether extract (at a concentration of $0.5-1.5 \mathrm{mg} / \mathrm{ml}$ ) showed the highest alpha amylase inhibition with high percent inhibition $(27.24 \pm 0.80 \%$ to $52 \pm 0.40 \%)$ and low $\mathrm{IC}_{50}$ value $(1.583 \mathrm{~g} / \mathrm{ml})$. Methanol $\left(\%\right.$ inhibition $=13.51 \pm 0.77 \%$ to $42.12 \pm 1.12 \%$, IC ${ }_{50}$ value $=$
$1.729 \mathrm{~g} / \mathrm{ml}$ ) and water (\% inhibition= $18.39 \pm 0.96 \%$ to $29.15 \pm 0.97$ $\%$, IC 50 value $=6.270 \mathrm{~g} / \mathrm{ml}$ ) extracts were also exhibit good level of alpha amylase inhibition (table 2).

Extracts with moderate inhibitory effect on alpha amylase activity

Stem

Alkaloid extract $(\%$ inhibition $=27.22 \pm 0.94 \%$ to $34.1 \pm 0.75 \%$, IC 50 value $=15.276 \mathrm{~g} / \mathrm{ml})$ and methanolic extract $(\%$ inhibition= $11.64 \pm 1.09 \%$ to $22.24 \pm 0.91 \%, \mathrm{IC}_{50}$ value $=16.469 \mathrm{~g} / \mathrm{ml}$ ) were recorded to have moderate alpha amylase inhibitory activity. (table 3)

\section{Root}

No extract was recorded to have moderate alpha amylase inhibitory activity.

Table 2: Extracts with maximum inhibitory effects on the alpha amylase activity

\begin{tabular}{|c|c|c|c|c|c|}
\hline S. No. & Name of extracts & Concentration $(\mathrm{mg} / \mathrm{ml})$ & \% inhibition & Regression equation & IC 50 Value \\
\hline \multicolumn{6}{|l|}{ Stem } \\
\hline \multirow[t]{3}{*}{1.} & Free flavonoid & 0.5 & $34.98 \pm 0.07$ & $Y=4.823+0.711 X$ & 1.774 \\
\hline & & 1.0 & $43.07 \pm 1.10$ & & \\
\hline & & 1.5 & $48.35 \pm 1.36$ & & \\
\hline \multirow[t]{3}{*}{2.} & Water & 0.5 & $16.33 \pm 0.75$ & $Y=4.356+1.108 X$ & 3.813 \\
\hline & & 1.0 & $27.3 \pm 1.25$ & & \\
\hline & & 1.5 & $32.13 \pm 1$ & & \\
\hline \multirow[t]{3}{*}{3.} & Pet ether & 0.5 & $26.07 \pm 0.94$ & $Y=4.585+0.68 X$ & 4.076 \\
\hline & & 1.0 & $36.43 \pm 1.45$ & & \\
\hline & & 1.5 & $37.3 \pm 0.81$ & & \\
\hline \multicolumn{6}{|l|}{ Root } \\
\hline \multirow[t]{3}{*}{1.} & Pet ether & 0.5 & $27.24 \pm 0.80$ & $Y=4.738+1.313 X$ & 1.583 \\
\hline & & 1.0 & $35.27 \pm 0.35$ & & \\
\hline & & 1.5 & $52 \pm 0.40$ & & \\
\hline \multirow[t]{3}{*}{2.} & Methanol & 0.5 & $13.51 \pm 0.77$ & $Y=4.521+2.015 X$ & 1.729 \\
\hline & & 1.0 & $35.7 \pm 0.43$ & & \\
\hline & & 1.5 & $42.12 \pm 1.12$ & & \\
\hline \multirow[t]{3}{*}{3.} & Water & 0.5 & $18.39 \pm 0.96$ & $Y=4.351+0.814 X$ & 6.270 \\
\hline & & 1.0 & $28.34 \pm 1.12$ & & \\
\hline & & 1.5 & $29.15 \pm 0.97$ & & \\
\hline
\end{tabular}

Table 3: Extracts with moderate inhibitory effects on the alpha amylase activity

\begin{tabular}{|c|c|c|c|c|c|}
\hline S. No. & Name of extracts & Concentration $(\mathrm{mg} / \mathrm{ml})$ & \% inhibition & Regression equation & IC $_{50}$ Value \\
\hline \multicolumn{6}{|l|}{ Stem } \\
\hline \multirow{3}{*}{1.} & Alkaloid & 0.5 & $27.22 \pm 0.94$ & $Y=4.511+0.413 X$ & 15.276 \\
\hline & & 1.0 & $31.55 \pm 0.65$ & & \\
\hline & & 1.5 & $34.1 \pm 0.75$ & & \\
\hline \multirow[t]{3}{*}{2.} & Methanol & 0.5 & $11.64 \pm 1.09$ & $Y=4.023+0.803 X$ & 16.469 \\
\hline & & 1.0 & $14.53 \pm 0.56$ & & \\
\hline & & 1.5 & $22.24 \pm 0.91$ & & \\
\hline
\end{tabular}




\section{Extracts with insufficient inhibitory effect on alpha amylase activity} Stem

Steroid and bound flavonoids were recorded for insufficient inhibitory activity with low percent inhibition and high $\mathrm{IC}_{50}$ values.

\section{Root}

Alkaloid, free flavonoid, bound flavonoid and steroids were found to have insufficient inhibitory activity with low $\%$ inhibition and high $\mathrm{IC}_{50}$ values.

The alpha-amylase inhibitory activity of different extracts of stem and root of Nerium oleander Linn. has been shown in fig. 1 and fig. 2 , respectively.

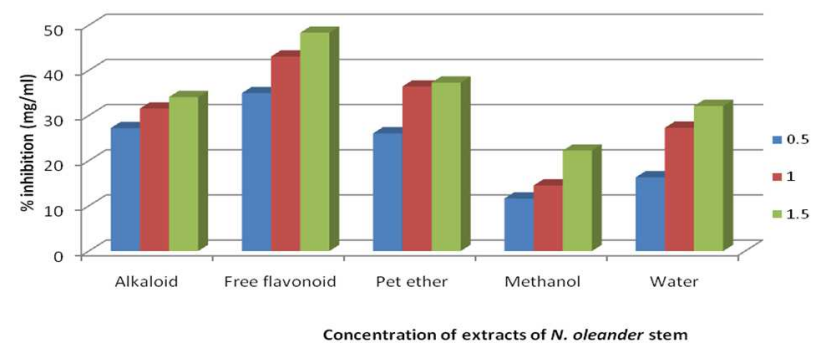

Fig. 1: Inhibition of alpha amylase by different extracts of $N$. oleander Line. Stem

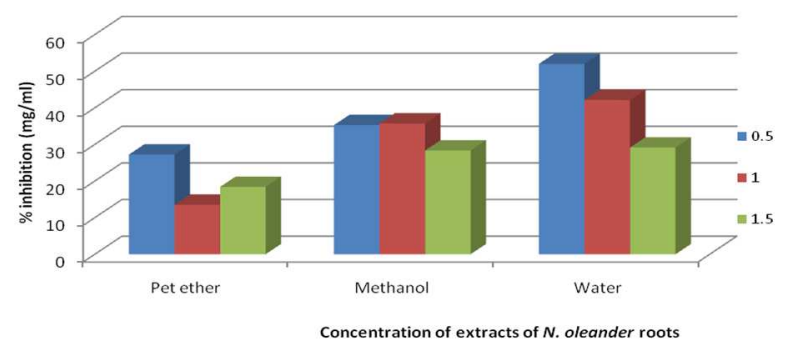

Fig. 2: Inhibition of alpha amylase by different extracts of $N$. oleander Line. Root

\section{DISCUSSION}

Diabetes is a chronic disease that occurs when the body cannot produce enough insulin or cannot use insulin effectively [23]. Type 2 diabetes is a common condition and a serious global health problem. In most countries, diabetes has increased alongside rapid cultural and social changes: ageing populations, increasing urbanisation, dietary changes, reduced physical activity and unhealthy behaviours [24]. A person's risk of developing Type 2 Diabetes Mellitus has been shown to be highly linked to obesity and any family history of diabetes [25]. The hyperglycemic condition causes increased glycosylation leading to biochemical and morphological abnormalities due to altered protein structure and develop the neuropathy, retinopathy, nephropathy and cardiomyopathy [26]. Antidiabetic drugs used as monotherapy or in combination to achieve better glycemic control. Each of the oral antidiabetic agents is however, associated with a number of serious adverse effects [27, $28]$ and none of the antidiabetic drugs could give a long term glycaemic control without causing the side effects [29]. Plant-based drugs have been known to be safe and cheaper and the plant plays the major role to manage the diabetes mellitus [30-32]. The current study takes us a step ahead in this direction. In this study, stem and root extracts of Nerium oleander Linn. were taken in search of new antidiabetic compound. We calculated $\mathrm{IC}_{50}$ values for determination of alpha-amylase inhibitory activities of extracts and found the free flavonoids of stem and pet ether and methanolic extracts of roots to have most hypoglycemic potential. Stem and root part of this plant were taken for the first time for the evaluation of antidiabetic potential in such way. Stem extracts were having a more pronounced effect on hyperglycemia than roots. Therapeutic potential of tested extracts were introduced from the results in maintaining the hyperglycemic condition.

\section{CONCLUSION}

Strong salivary alpha-amylase inhibitory potential of stem and root extracts of Nerium oleander Linn. was concluded from the present study. Low $\mathrm{IC}_{50}$ values were the indication of high inhibition power of tested extracts. Extracts of the stem were observed to have more potential of inhibition than root extracts, but still extracts of both parts are important in search of natural amylase inhibitors. This is considered to be the most interesting aspect to explore and elucidate the possible mechanism responsible for the significant anti-diabetic activity. Further research investigations may be required to isolate the actual constituents responsible for the antidiabetic activity.

\section{ACKNOWLEDGEMENT}

The authors would like to extend their sincere thanks and appreciation to the Department of Botany, the University of Rajasthan for providing adequate laboratory facilities and providing required materials needed for the study.

\section{CONFLICT OF INTERESTS}

\section{No conflict of interests}

\section{REFERENCES}

1. World Health Organization. Diabetes Programme, Department of Chronic Diseases and Health Promotion; Facts and fig. SheetDiabetes, Geneva, Switzerland; 2006.

2. Yassin MM, Ashour AA, Elyazji NR. Alterations in body weight, protein profile, non-protein nitrogen constituents and kidney structure in diabetic rats under glibenclamide treatment. J Islam Univ Gaza 2004;12:65-82.

3. Mazumdar BC, Mukhopadhyay PM. Principles and Practices of Herbal Garden. Daya Publishing House, Delhi; 2006. p. 1.

4. Zimet P, Alberti KGMM, Shaw J. Global and societal implications of diabetic rats. Nature 2001;414:782-6.

5. Kadali VN, Sandeep BV. Anti-hyperglycemic plants used by the traditional healer of west Godavari District, Andhra Pradesh, India. Int J Pharmacogn 2015;2:473-77.

6. Wadkar KA, Magdum CS, Patil SS, Naikwade NS. Antidiabetic potential and Indian medicinal plants. J Herbal Med Toxicol 2008;2:45-50.

7. Hsu YJ, Lee TH, Chang CL, Huang YT, Yang WC. Antihyperglycemic effects and mechanism of Bidens pilosa water extract. J Ethnopharmacol 2009;18:379-83.

8. Jouad H, Haloui M, Rhiouani H, El HJ, Eddouks M. Ethnobotanical survey of medicinal plants used for the treatment of diabetes, cardiac and renal diseases in the North centre region of Morocco (Fez-Boulemane). J Ethnopharmacol 2001;77:175-82.

9. Bnouham M, Mekhfi H, Legssyer A, Ziyyat A. Medicinal plants used in the treatment of diabetes in Morocco. Int J Diabetes Metab 2002;10:33-50.

10. Tahraoui A, El-Hilaly J, Israili ZH, Lyoussi B. Ethnopharmacological survey of plants used in the traditional treatment of hypertension and diabetes in south-eastern Morocco (Errachidia province). J Ethnopharmacol 2007;110:105-17.

11. Hussain AM, Abbasi MSA, Hussain N, Majid SA. A survey of important indigenous medicinal plants of district Bhimber Azad Jammu and Kashmir, Pakistan. Int J Adv Res 2013;1:635-44.

12. Rachid A, Rabah D, Farid L, Zohra SF, Houcine B, Nacera B. Ethnopharmacological survey of medicinal plants used in the traditional treatment of diabetes mellitus in the North Western and South Western Algeria. J Med Plants Res 2012;6:2041-50.

13. Dey P, Saha MR, Chowdhuri SR, Sen A, Sarkar MP, Haldar B, et al. Assessment of anti-diabetic activity of an ethnopharmacological plant Nerium oleander through alloxan induced diabetes in mice. J Ethnopharmacol 2015;161:128-37.

14. Swathi K, Ravi Shankar K. Anti-diabetic activity of ethanolic extract of Nerium oleander flowers in alloxan induced diabetic rats. Int J Biopharm Res 2014;3:212-5. 
15. Mwafy SN, Yassin MM. Antidiabetic activity evaluation of glimepiride and Nerium oleander extract on insulin, glucose levels and some liver enzymes activities in an experimental diabetic rat model. Pak J Biol Sci 2011;14:984-90.

16. Sudha P, Zinjarde SS, Bhargava SY, Kumar AP. The potent $\alpha$ amylase inhibitory activity of Indian Ayurvedic medicinal plants. BMC Complementary Altern Med 2011;11:5.

17. Sandhya S, Sai Kumar P, Vinod KR, David Banji, Kumar K. Plants as potent anti-diabetic and wound healing agents-a review. Hygeia: J Drugs Med 2011;3:11-9.

18. Ramawat KG, Merillon JM. Biotechnology: Secondary Metabolites. Science Pub Inc.; 2000.

19. Subramanian SS, Nagarjan S. Flavonoids of the seeds of Crotolaria retusa and Crotolaria striata. Curr Sci (India) 1969;38:65.

20. Tomita Y, Uomori A, Minato H. Steroidal sapogenins and sterols in tissue cultures of Dioscorea tokora. Phytochemistry 1970;9:111-4.

21. Xiao Z, Storms R, Tsang A. A quantitative starch-iodine method for measuring alpha-amylase and glucoamylase activities. Anal Biochem 2006;351:146-8.

22. Miller GL. Use of dinitro salicylic acid reagent for determination of reducing sugar. Anal Chem 1959;31:426-8.

23. Zimmet P, Cowie C, Ekoe JM, Shaw J. Classification of diabetes mellitus and other categories of glucose intolerance. In: International Textbook of Diabetes Mellitus; 2004.

24. World Health Organization. Prevention of diabetes mellitus: report of a WHO Study Group. Geneva; 1994.

25. Sandoval S. Pima Indian Diabetes susceptibility differs significantly from European susceptibility. Biochem 2009;118:1-8.
26. Arky RA. Clinical correlates of metabolic derangements of diabetes mellitus. Complications of diabetes mellitus. WB Saunders. Philadelphia; 1982. p. 16-20.

27. Moller DE. New drug targets for type 2 diabetes and the metabolic syndrome. Nature 2001;414:821-7.

28. Nwaegerue E, Nweke IN, Ezeala CC, Unekwe PC. Glucose lowering effect of leaf extracts of Viscum album in normal and diabetic rats. J Res Med Sci 2007;12:235-40.

29. Singh S, Loke YK, Furberg CD. Thiazolidinediones and heart failure: a teleo-analysis. Diabetes Care 2007;30:2148-53.

30. Ahmed I, Adeghate E, Cummings E, Sharma AK, Singh J. Beneficial effects and mechanism of action of Momordica charantia juice in the treatment of streptozotocin-induced diabetes mellitus in rat. Mol Cell Biochem 2004;261:63-70.

31. Karunanayake EH, Tennekoon KH. Search of novel hypoglycemic agents from medicinal plants. In: Sharma AK. Diabetes mellitus and its complications. An update. Macmillan India Ltd, New Delhi, India; 1993.

32. Ribnicky DM, Kuhn P, Poulev A, Logendra S, Zuberi A, et al. Improved absorption and bioactivity of active compounds from an anti-diabetic extract of Artemisia dracunculus L. Int J Pharm 2009;370:87-92.

\section{How to cite this article}

- Meenakshi Fartyal. Nerium oleander Linn. in vitro alphaamylase inhibitory potential of stem and root extracts. Int J Curr Pharm Res 2017;9(2):37-41. 